\title{
Environmental Survey of Rotavirus in Sewage Water within Maiduguri Metropolis, Nigeria
}

\author{
Kadai, Aisha Muhammad ${ }^{1}$, Bello, Hauwa $S^{2}$, Ghamba, Peter Elisha ${ }^{1}$, \\ Dauda, Fatima Aminu ${ }^{2}$, Abdullahi, Idris Nasir ${ }^{3}$, \\ ${ }^{1}$ W.H.O National Polio Laboratory, University of Maiduguri Teaching Hospital, P.M.B \\ 1414, Maiduguri, Nigeria. \\ ${ }^{2}$ Department of Medical Microbiology, University of Ilorin, Ilorin, \\ Nigeria. \\ ${ }^{3}$ Department of Medical Laboratory Science, Faculty of Allied Health Sciences, College \\ of Medical Sciences, Ahmadu Bello University, Zaria, Nigeria.
}

Corresponding Author Idris Nasir Abdullahi

Mobile: $+2348027771068$

\section{E mail:} eedris888@yahoo.com inabdullahi@abu.edu. $\underline{n g}$

Key words: Environmental surveillance, Virus detection, Rotavirus, Sewage water, Nigeria
Background and study aim: Inadequately treated water supply and unhygienic food consumption are the major sources of contracting feco-orally transmitted viral pathogens, including Rotavirus. This prospective study aimed to assess the presence of Rotavirus in sewage, underground and surface waters collected from different locations within Maiduguri Metropolis, Nigeria.

Materials and Methods: A total of 170 sewage and water samples (underground and surface waters) were collected from various sources in high-density and lowdensity areas of the Maiduguri metropolis. A modified adsorption- elution method for concentration of enteric viruses in sewage and water samples and detection of the presence of rotavirus (if present) was done using Enzyme linked immunesorbent assay (ELISA). The viruses in water were concentrated by negatively charged membrane filtration, eluted with $0.05 \mathrm{M}$ Glycine at $\mathrm{pH} 11.5$, and reconcentrated by centrifugation at $12,000 \mathrm{rpm}$ for one hour.

Results: Out of the 60 domestic sewage samples collected from high-density areas, $8.3 \%$ were positive for rotavirus antigen, whereas none of the samples from low-density areas were positive. In addition, rotavirus antigen was not detected in underground and surface water samples. The temperature range of the 5 rotavirus positive samples was 23$30^{\circ} \mathrm{C}$. All the 5 positive samples had alkaline $\mathrm{pH}$ that ranged between 8 and 9 .

Conclusion: This study has demonstrated the persistence of rotavirus in sewage and its possible transmission through contaminated food and poor treated water especially in unvaccinated children.

\section{INTRODUCTION}

Rotavirus is a member of the Reoviridae family. It is a nonenveloped and highly segmented virus with double-stranded RNA genome [1]. Rotavirus is transmitted via fecaloral route, person to person direct contact, or by consumption of food and water contaminated with human feces [2]. After replication in the gastrointestinal tract, rotavirus is shed at very high concentrations in feces and can persist in the environment for long period [3]. Rotavirus is highly resistant to processes used in wastewater treatment plants, which can favor their spread into the environment [4], particularly in surface waters.

Rotavirus is the major cause of acute gastroenteritis that leads to deaths in infants and young children worldwide. Before the introduction of rotavirus vaccines, rotavirusassociated mortality was very higher in sub-Saharan Africa [5]. Although rotavirus can infect all age groups, children $<5$ years are mainly affected [5]. In recent time, morbidity and mortality due to rotavirus infections has reduced due to adoption of mass vaccination program against the virus. However, rotavirus still causes about 192,700 deaths per year in children 
$<5$ years mostly in low-and middle-income countries [6]. In Nigeria, they have been reports of various genotypes including mixed and unusual genotype combination isolated from young children and environmental samples $[\mathbf{7}, \mathbf{8}$, 9]. This might have undermined the public health efforts in controlling pediatric rotavirus infection in Nigeria.

Essentially, rotavirus had been implicated in waterborne gastroenteritis sporadic outbreaks [10]. In addition, sewage contains so many enteric viruses including rotavirus that could be shed by individuals who are either asymptomatic or clinically sick [11]. Thus, the significance of the surveillance of rotavirus in community sewage for assessment of the potential health threat in the population cannot be overemphasized.

The roles of sewage, underground and surface waters in the occurrence and spread of rotavirus infection in Northern Nigeria has not been studied previously. In this study the environmental surveillance of rotavirus within Maiduguri Metropolis was carried out to generate data that could be used in the effective management of public and domestic water supplies as well as implementation of appropriate preventive and control measures against transmission of rotavirus and other waterborne viruses. Hence, this prospective study aimed to investigate the presence of rotavirus in sewage, underground and surface waters collected from different locations within Maiduguri Metropolis, Nigeria.

\section{MATERIALS AND METHODS}

\section{Study Area:}

This study was conducted within Maiduguri Metropolitan council of Borno State, Northeastern Nigeria.

Maiduguri, the state capital of Borno state is the largest city of the six states in the Northeastern Nigeria. It lies on latitude $11^{\circ}$ north and longitude $15^{\circ}$ east. It occupies an area of 50,778 square kilometers. Borno state shares borders with republic of Niger to the North, Chad to the North East and Cameroun to the East. Maiduguri have an estimated population of $1,112,449$ people according to GeoNames geographical database. The occupation of most people in the area are farming, fishing, and rearing of live stocks. The inhabitants of Maiduguri often depend on well, borehole, rain water and stream for domestic use. According to the 2006 Nigerian National Population census, less than $5 \%$ of Maiduguri populace had access to portable tap water.

\section{Sample Collection and Processing:}

A total of 170 samples were collected from selected high- and low-density areas of the Metropolis From the high-density area, 60 samples were collected from sewage, 10 samples from underground (bore-holes), and 22 samples from surface water. From low density area, 50 samples were collected from sewage, 10 samples from bore-hole, and 18 samples from surface water. Samples were collected in sterile one-liter bottle. The samples were filtered during collection to remove large debris. The back of the sample containers was decontaminated with $10 \%$ hypochlorite. Samples were transported to the laboratory on ice pack and stored at $-20^{\circ} \mathrm{C}$ before analysis (within 48 hours). The temperature and $\mathrm{pH}$ of all the samples (sewage and water) were measured and recorded accordingly. The samples were later concentrated by adsorption - elution method as previously described by Wang et al [12] and analyzed by Enzyme Linked Immunosorbent Assay (ELISA) for the presence of rotavirus antigens in the water elutes.

\section{Concentration of Water Samples:}

The concentration of water samples was carried out essentially as described by Wang et al [12]. About $500 \mathrm{~mL}$ of the water samples were individually centrifuged in $50 \mathrm{~mL}$ tubes at 3000 $\mathrm{rpm}$ for 30 minutes at $4^{\circ} \mathrm{C}$. The supernatants were transferred into glass beakers and $10 \mathrm{ml}$ of 2.5M $\mathrm{MgCL}_{2}$ was added and thoroughly mixed using magnetic stirrer. The $\mathrm{pH}$ was adjusted to 3.5 using $1 \mathrm{~N} \mathrm{HCL} \mathrm{(3-5} \mathrm{mL)} \mathrm{on} \mathrm{magnetic} \mathrm{stirrer.}$

The mixture was filtered by means of adsorption using a $47 \mathrm{~mm}$ filter and $50 \mathrm{~mL}$ syringe. The filter cartridge was opened, the filter cut and the pieces were placed on petri dish. The pieces of filter membrane were placed in a $50 \mathrm{~mL}$ centrifuge tube, and $10 \mathrm{~mL}$ of the elution buffer $0.05 \mathrm{M}$ Glycine $\mathrm{pH} 11.5$ and glass beads $(1-3 \mathrm{~mm})$ were added. The content of the tube was mixed on vortex mixer for 1-3 minutes and the supernatant was immediately transferred to $15 \mathrm{~mL}$ centrifuge tube (Elution). The $\mathrm{pH}$ of the elutes was immediately adjusted to 7.0 using $1 \mathrm{~N}$ 
$\mathrm{NaoH}$ or $1 \mathrm{~N} \mathrm{HCL}$. The water elutes obtained were subjected to hi- speed centrifugation (reconcentration) at $12000 \mathrm{rpm}$ for $15 \mathrm{~min}$ at $4^{\circ} \mathrm{C}$, and filtered using MILLIPORE: millex filter, SLHV) 33RS, $0.45 \mu \mathrm{m}$. The elute was finally aliquoted into $2 \mathrm{~mL}$ cryovial tube and stored at $20^{\circ} \mathrm{C}$ prior to laboratory analysis (within 48 hours).

\section{Rotavirus Enzyme Immunoassay of Sample Elutes}

This test was conducted in accordance with the instruction by kit manufacturer (Epitope Diagnostics, Inc., San Diaego, USA). The micro wells were pre-coated with anti-rotavirus polyclonal antibody. The ELISA for detection of rotavirus antigen in the sample elutes was carried out as follows: One hundred microliters each for sample (elute), negative control, and positive control and $100 \mu \mathrm{L}$ of the conjugate were added to each well the microtiter plate was then covered and incubated at $20-30^{\circ} \mathrm{C}$ for 60 minutes. The content of the wells was decanted and washed with diluted wash buffer (350-400 $\mu \mathrm{L})$ per well. The fluid from each well after each wash was shaken out and the washing was repeated 5 times. After the last wash, the plate was inverted and tapped on an absorbent paper to remove traces of wash buffer. One hundred microliter $(100 \mu \mathrm{L})$ of the substrate was added to each micro well and the plate was covered and incubated at $20-30^{\circ} \mathrm{C}$ for 10 mins. The substrate reaction was stopped by the addition of $100 \mu \mathrm{L}$ of stop solution (Sulphuric acid) to each well. The plate was immediately read on an ELISA plate reader at a wavelength of $450 \mathrm{~nm}$. The presence or absence of Rotavirus antigen was determined by based on the instructions of Kit manufacturer.

\section{Statistical Analysis:}

Data obtained from this study were presented in tabular forms. Frequencies and percentage of positive samples in relation to site of sample collection were calculated. Data were analyzed using Statistical Package for Social Sciences (SPSS) version 26 (California Inc., USA).

\section{RESULTS}

One hundred and seventy water samples collected from various sources of high density and low-density areas of Maiduguri metropolis were analyzed for the presence of Rotavirus. Rota virus was detected in five out of one hundred and seventy (5/170) samples by ELISA (Table 1).

Out of all the water samples collected and analyzed, 110 were sewage samples, 40 underground water (bore-hole and Dam) and 20 surface water samples (Table 2). Out of the 60 sewage samples obtained from high density areas, $5(8.3 \%)$ samples were positive for rotavirus antigen, whereas none of the samples collected from underground and surface water were positive for rotavirus (Table 1). None of the samples collected from sewage, underground or surface water in the low-density areas of the Maiduguri metropolis was positive for rotavirus. In this study, rotavirus was not detected in any of the underground (bore-hole and dam water) and surface water samples obtained from both highand low-density areas of the metropolis. The temperature range of the 5 rotavirus positive samples were within of $23-30^{\circ} \mathrm{C}$ (table 3 ). All the five rotavirus positive samples had alkaline $\mathrm{pH}$ that ranged between 8 and 9 (Table 4)

Table (1): Detection rate of Rotavirus in Water Samples obtained from High Density Areas.

\begin{tabular}{|c|c|c|}
\hline \multicolumn{1}{|c|}{ Water Source } & No. of samples & No. positive (\%) \\
\hline Sewage & 60 & $5(8.3)$ \\
\hline Underground & 100 & $0(0.0)$ \\
\hline Bore-hole & 10 & $0(0.0)$ \\
\hline Surface water & 12 & $0(0.0)$ \\
\hline Dam water & 10 & $0(0.0)$ \\
\hline Total & 90 & $5(5.4)$ \\
\hline
\end{tabular}


Table (2): Comparison of Water Samples Collected from Low- and High-density areas.

\begin{tabular}{|l|c|c|c|}
\hline & Sewage (\% positive) & Underground & Surface \\
\hline High density & $60(8.3)$ & $100(0.0)$ & $22(0.0)$ \\
\hline Low density & $50(0)$ & $10(0)$ & $18(0)$ \\
\hline Total & $110(5.5)$ & $20(0.0)$ & $40(0.0)$ \\
\hline
\end{tabular}

Meaning of terms:

High density areas: congested areas of the metropolis

Low density areas: non congested areas.

Table (3): Temperature Ranges of Samples Collected in High Density Areas

\begin{tabular}{|c|c|}
\hline Temperature Range $\left({ }^{\mathbf{0}} \mathbf{C}\right)$ & No. of sample (No. of Rotavirus positive) high density areas \\
\hline $20-23$ & $31(1)$ \\
\hline $24-27$ & $46(2)$ \\
\hline $28-31$ & $13(2)$ \\
\hline $32-34$ & $2(0.0)$ \\
\hline Total & 92 \\
\hline
\end{tabular}

Table (4): $\mathrm{pH}$ values of Water Samples collected from High- and Low-Density Areas.

\begin{tabular}{|c|c|c|}
\hline $\mathbf{p H}$ & No. of samples (High density) & No. samples (low density) \\
\hline 7 & $16(0.0)$ & 19 \\
\hline 8 & $69(5)$ & 50 \\
\hline 9 & $5(1)$ & + \\
\hline Total & 92 & 78 \\
\hline
\end{tabular}

High density areas $=$ congested areas of the metropolis

Low density areas $=$ non-congested areas

\section{DISCUSSION}

Most developing countries do not have the technical capacity and manpower to run molecular techniques for the environmental surveillance of rotavirus and other viruses of public and environmental health significance. Hence, the need for an affordable and effective protocol for this purpose. Since the densities of viruses in water are usually low, a virus concentration method is required. It has been shown that the use of modified adsorptionelution technique in optimum condition is an effective method for Rotavirus concentration from water samples.

We found that 5 out of 60 sewage samples $(8.3 \%)$ that were collected from high density areas were positive for rotavirus while none of the sewage samples collected from low density areas were positive for Rotavirus. This is in consonance with the study of Kittigul et al [13] who reported $8 \%$ (4 out of 48 ) rotavirus antigen detection rate in domestic sewage using ELISA in Thailand and $7.4 \%$ of treated sewage reported by Abd El-Daim et al [14] in Egypt. However, the detection rate in our study was lower compared to the $32.3 \%$ rotavirus detected by $\mathrm{He}$ et al [15] in china and $61.5 \%$ by Atabakhsh et al [16] in Iran. These differences may reflect the level of endemicity, timing of the study and environmental hygienic status as at time of conducting these studies. Moreover, the current viral prevalence is relatively high when compared with other previous reports. Differences in the detection rate of rotavirus might be due to the variations in sensitivity of virus recovery and detection methods employed by these studies [14]. For instance, 2 reports from Thailand documented detection rates $8 \%$ and $0 \%$ from rotavirus positive cases of untreated sewage specimens by ELISA [13, 17]. However, $21 \%$ detection rate was reported using immunofluorescence in a study from Brazil [18].

Rotavirus was not detected in any of the underground (bore-hole and Dam water) and surface water in this study. This is similar to the study reported by Kittigul et al [13] where rotavirus was not detected in surface water. Worthy of note is that temperature is a significant factor for virus survival. The lower

Kadai et al., Afro-Egypt J Infect Endem Dis 2020;10(2)207-212

https://aeji.journals.ekb.eg/

http://mis.zu.edu.eg/ajied/home.aspx 
the temperature the longer viruses persist and survive. The temperature readings of the 5 rotavirus positive samples were between 23$30^{\circ} \mathrm{C}$. These values were within the temperatures range of $27-31^{\circ} \mathrm{C}$ from samples positive for rotavirus by Kittigul et al [19]. However, this is contrary to temperature reported by an earlier study by Kittigul et al [13] where four samples positive for rotavirus had temperature range between $30-31^{\circ} \mathrm{C}$.

It has been reported that rotavirus can survive for a long time at alkaline $\mathrm{pH}$ range of 11.0-11.5 [20]. The five samples positive for rotavirus in our study had alkaline pHs. This is similar to the report from Kittigul et al. [13], where 3 out of the 4 positive samples had alkaline pHs. As demonstrated from the current study, rotavirus can survive at relatively high temperature and $\mathrm{pH}$. Hence, this reflect their ability to survive on the environment for long periods and this contribute to their high degree of persistence and transmission.

\section{CONCLUSION}

This study has demonstrated the persistence of rotavirus in sewage and possible transmission through contaminated food and poor treated water especially in unvaccinated children. These put together highlights the public health significance of rotavirus in environmental samples. It is recommended that periodic environmental surveillance of rotavirus be done preferably using molecular techniques in combination with antigen-based enzyme immunoassays. In addition, there is a need for improved community health awareness through educating the populace on how best to observe proper environmental hygiene.

\section{Ethical consideration:}

This study was reviewed and approved by the Ethical Research Committees of Borno State Ministry of Health and University of Maiduguri, before commence of study. All data were confidentially analyzed and anonymously.

Conflict of Interest: None declared

Financial Support: None received

\section{REFERENCES}

1. Center for Disease Control and prevention. Rotavirus. 2019.

https://www.cdc.gov/Rotavirus/clinical.html Last Accessed 7th April, 2020

2. Kargar M, Javdani N, Najafi A, Tahamtan Y. First molecular detection of group A Rotavirus in urban and hospital sewage systems by nested RT-PCR in Shiraz, Iran. J Environ Health Sci Eng 2013;11:4.

3. Ruggeri FM, Bonomo P, Ianiro G, Battistone A, Delogu R, Germinario C, et al. Rotavirus genotypes in sewage treatment plants and in children hospitalized with acute diarrhea in Italy in 2010 and 2011. Appl Environ Microbiol 2015; 81:241-249. doi:10.1128/AEM.02695-14.

4. Petrinca AR, Donia D, Pierangeli A, Gabrieli R, Degener AM, Bonanni E, et al. Presence and environmental circulation of enteric viruses in three different wastewater treatment plants. $J$ Appl Microbiol 2009; 106:1608-1617. http://dx.doi.org/10.1111/j.1365-

2672.2008.04128.x.

5. Aminu M, Ahmad AA, Umoh JU, Dewar J, Esona MD, Steele AD, et al. Epidemiology of Rotavirus infection in North-Western Nigeria. $J$ Trop Pediatr 2008;54:340-2.

6. Ouermi D, Soubeiga D, Nadembega WM, Sawadogo PM, Zohoncon TM, Obiri-Yeboah D, et al. Molecular epidemiology of Rotavirus in children under five in Africa (2006-2016): A systematic review. Pak J Biol Sci 2017; 20:5969.

7. Motayo BO, Adeniji AJ, Faneye AO. First molecular detection and VP7 (G) genotyping of group A Rotavirus by semi-nested RT-PCR from sewage in Nigeria. Rev Inst Med Trop Sao Paulo 2016; 58:74.

8. Amadu DO, Abdullahi IN, Emeribe AU, Musa PO, Olayemi L, Yunusa T, et al. Molecular characterization of Rotavirus genotype-A in children with acute diarrhea attending a tertiary hospital in Ilorin, Nigeria. Int J Health Allied Sci 2019; 8:187-92.

9. Oluwatoyin JM, Adeyemi AO, Famurewa O, Svensson L, Nordgren J. Molecular epidemiology of Rotavirus and norovirus in IleIfe, Nigeria: high prevalence of G12P[8] Rotavirusstrains and detection of a rare norovirus genotype. J Med Virol 2012; 84:14891496. http://dx.doi.org/10.1002/jmv.23343 
10. Zhou N, Dong LV, Wang S, Lin X, Bi Z, Wang $\mathrm{H}$, et al. Continuous detection and genetic diversity of human Rotavirus A in sewage in eastern China, 2013-2014. Virol J 2016; 13:153 DOI 10.1186/s12985-016-0609-0

11. Koopmans $\mathrm{M}$, von Bonsdorff $\mathrm{CH}$, Vinje $\mathrm{J}$, de Medici D, Monroe S. Foodborne viruses. FEMS Microbiol Rev 2002; 26:187-205. http://dx.doi.org/10.1111/j.15746976.2002.tb00610.x

12. Wang H, Tao Z, Li Y, Lin X, Yoshida H, Song L, et al. Environmental surveillance of human enteroviruses in Shandong Province, China, 2008 to 2012: serotypes, temporal fluctuation, and molecular epidemiology. Appl Environ Microbiol 2014; 80:4683-91.

13. Kittigul L, Raengsakulrach B, Siritantikorn S, Kanyok R, Utrarachkij F, et al. Detection of poliovirus, hepatitis A virus and Rotavirus from sewage and water samples. Southeast Asian J Trop Med Public Health 2000; 31(1): 41-46.

14. Abd El-Daim SE, Mohamed Shaheen NF, Hosseney EN, Elhosainy AM, Nehal IA, Elmahdy ME, et al. Molecular Detection and Genotyping of Group A Rotavirus by Multiplex Semi-Nested RT-PCR in Sewage Water and Sludge. J Microbiol Biotechnol 2019; 2019, 4(1): 000141 DOI: 10.23880/oajmb-16000141
15. He XQ, Cheng L, Zhang DY, Xie XM, Wang $\mathrm{DH}$, Wang Z. One-year monthly survey of rotavirus, astrovirus and norovirus in three sewage treatment plants in Beijing, China and associated health risk assessment. Water Sci Technol 2011; 64(6):1202-10.

16. Atabakhh P, Kargar M, Doosti A. Molecular detection and genotyping of group A Rotavirus in ttwo wastewater treatment plants, Iran. Braz J Microb 2020; 51 (1); 197-203.

17. Kittigul L, Khamoun P, Sujirarat D, Utrarachkij F, Chitpirom K. An improved method for concentrating Rotavirus from water samples. Memorias do Instituto Oswaldo Cruz 2001; 96(6): 815-821.

18. Mehnert DU, Stewien KE. Detection and distribution of Rotavirus in raw sewage and creeks in Sao Paulo, Brazil. Appl Environ Microbiol 1993; 59(1): 140-143.

19. Kittigul L, Ekchaloemkiet S, Utrarachkij F, Siripanichgon K, Sujirarat D, Pungchitton S, et al. An efficient virus concentration method and RT-nested PCR for detection of Rotaviruses in environmental water samples. J Virol Methods 2005; 124: 117-122.

20. Grassi T, Bagordo F, Idolo A, Lugoli F, Gabutti G, De Donno A. Rotavirus detection in environmental water samples by tangential flow ultrafiltration and RT-nested PCR. Environ Monit Assess 2010; 164:199-205 DOI 10.1007/s10661-009-0885-x 